\title{
Transitivity and identity construction for pedagogical purposes: analysis of an interview with comedian Chico Anysio
}

\author{
Renan Silva da Piedade \\ Pontifícia Universidade Católica do Rio de Janeiro - PUC-RIO / CAPES
}

\begin{abstract}
This article analyzes transitivity (HALLIDAY, 2004) in an interview with comedian Chico Anysio, considering that this lexical-grammatical category, based on Systemic Functional Linguistics (HALLIDAY; HASAN, 1989; HALLIDAY; MATTHIESSEN, 2004; EGGINS, 1994), can be adopted as a methodological tool for identity studies and may be used for pedagogical purposes. The local construction of the interaction and its relationship with real-life situations permeating it will be considered, mainly regarding the applicability of such notions in didactic contexts. The analysis, with a descriptive-interpretive basis, may serve the various social sciences, giving evidence of how individuals construct identities and their respective meanings.
\end{abstract}

Key words: systemic functional linguistics, transitivity system, identity construction, pedagogical context

\begin{abstract}
Resumo
Este artigo pretende analisar a transitividade (HALLIDAY, 2004) em uma entrevista ao comediante Chico Anysio, considerando que essa categoria léxico-gramatical, baseada na Linguística Sistêmico Funcional (HALLIDAY; HASAN, 1989; HALLIDAY; MATTHIESSEN, 2004; EGGINS, 1994), pode ser adotada como um instrumento metodológico para os estudos de identidade e utilizada para fins pedagógicos. A construção local da interação e sua relação com as situações da vida real que a permeiam serão contempladas, principalmente no que se refere à aplicabilidade de tais noções em contextos educacionais. A análise, de base descritiva-interpretativa, pode servir às várias ciências sociais, evidenciando como os indivíduos constroem identidades e seus respectivos significados.
\end{abstract}

Palavras-chave: linguística sistêmico funcional, sistema de transitividade, construção de identidade, contexto pedagógico

\section{INTRODUCTION}

It is known that classrooms constitute a vast environment when it comes to possibilities of developing pedagogical work. Today, many of us, as language educators, seek to increase the students' communicative competence, which represents a change of perspective if compared to more traditional ways of teaching. Such a change 
is possible due to the understanding of language as an instrument of communication and action, privileging its functionality.

Based on this idea, researchers who focus on the pedagogical practices of language teaching (CUNHA; OLIVEIRA; MARTELLOTA, 2003) have brought the functions of language to the heart of their discussions, which is, to a certain extent, my objective in writing this paper.

Having in mind the consolidation of this paradigm and seeing language, as well as its grammar, as an inexhaustible source of meanings, in this article I attempt to investigate linguistically one of the grammatical resources responsible for the construction of experiences: the transitivity system (HALLIDAY, 2004). More specifically, I will do this through the analysis of a televised interview with comedian Chico Anysio, so that I can observe the interviewee's identities being created through discourse as well as the pedagogical potential of such an approach.

I decided to include this research in the Systemic Functional Linguistics (SFL) field because this theory provides a greatly enhanced insight into text, offers the right instruments to analyze aspects related to form and content, and concentrates on functions and/or purpose of the text (MARTÍNEZ LIROLA, 2006).

Regarding the theoretical assumptions of Systemic Functional Linguistics (HALLIDAY, 2004) and the notion of identity in Moita Lopes (2002), it is understood that working with real discourse and social roles inside the classroom is necessary contrary to what some may think - and that grammatical knowledge is essential for students to develop their communicative skills, and thus achieve greater verbal proficiency.

To do so, this article is organized into six parts, the first of which is this introduction. The second part explains the theoretical foundations, and the methodology adopted is described in the following section. In the fourth part, the data is analyzed, and, in the fifth section, I establish a connection between the analysis and its pedagogical potential. In the last section, I present the final considerations.

\section{THEORETICAL FRAMEWORK}

The functionalism of Michael A K Halliday and some other academics (HALLIDAY; HASAN, 1989; EGGINS, 1994; THOMPSON, 2003; MARTIN; ROSE, 2003; MARTIN; WHITE, 2005), called Systemic Functional Linguistics (SFL), is a 
theory of language as a matter of choice. It is a way of looking into texts in terms of the meanings they create. In the area of language studies, SFL is opposed to formalism, because its focus of interest is the use of language to make interaction between speakers possible. In other words: its orientation is intrinsically social.

Systemic Functional Linguistics basically seeks to demonstrate how language is used, since any statement is inserted in a real context. It is also important to mention that language, according to this view, does not exist arbitrarily. It evolves to meet the speaker's needs, outlining a natural system appropriate to the surrounding reality in which everything may be combined and explained according to the verbal production of individuals.

Moreover, a very comprehensive study of text (object of SFL analysis) is found in Halliday and Hasan's (1976) treatment of features of English texts. In their work Cohesion in English, they define the notion of 'text' by saying:

\begin{abstract}
Text is used in linguistics to refer to any passage, spoken or written, of whatever length, that does form a unified whole [...]. A text is a unit of language in use. It is not a grammatical unit, like a clause or a sentence; and it is not defined by its size. A text is sometimes envisaged to be some kind of super-sentence, a grammatical unit that is larger than a sentence but is related to a sentence in the same way that a sentence is related to a clause, a clause to a group and so on [...]. A text is best regarded as a semantic unit; a unit not of form but of meaning. (HALLIDAY; HASAN, 1976, p.2)
\end{abstract}

In addition, there are two key concepts that must be taken into account in the analysis of any piece of text: context of culture and context of situation. The first is related to the ways different cultures use language (treatment of forms, expression of emotions, academic discourse, etc). It is believed that any kind of linguistic interaction is not just about sound and signals. In fact, it involves the entire historical context of a certain community, as well as the culture of its members. The second concept consists of more particular language variations within each culture, depending on how/when/why they occur. The context of situation corresponds to extralinguistic characteristics of texts, the environment in which meanings are being exchanged. According to Halliday and Hasan (1989), it is comprised of three elements: field (what is going on in the interaction), relations (who are the participants involved in the situation) and mode (the symbolic organization of the text being created).

Besides, the parameters of the context of situation affect our linguistic choices in the sense that they reflect the three functions of language (HALLIDAY, 1989). These are called metafunctions of language: the ideational, interpersonal and textual. The first represents or constructs the meanings of our experiences through the transitivity system. 
The second, realized through mood and modality, expresses the role played by the speakers, showing their attitudes towards the others, as well as their actions in relation to the topic approached. The third has to do with the flow of information and the text organization, having as a basis the theme/rheme system.

In conclusion, I could say that SFL offers the necessary tools to investigate any piece of language, and, at the same time, it allows us to understand the functionality of what we say/write, regarding by whom/when/where/how/to whom discourse is being produced.

One way of analyzing language and the meaning it creates is through the use of the transitivity system ${ }^{1}$ (HALLIDAY, 2004). This system, as designed by Systemic Functional Linguistics, enables us to identify the human actions, the activities being expressed in speech and the reality being portrayed, as it is through language that we, speakers, talk about our experiences of people, objects, abstractions, qualities, states and relationships in our inner and outer world. It is composed of three elements: processes (what is being done), participants (who is doing the action) and circumstances (under what conditions the action is being done), each one of them being responsible for a part of reality and for a particular construction of meanings.

Within this idea, the transitivity system has its subcategories. Three types of processes are seen as key: material, mental and relational. The first is the process of 'doing'. It expresses the notion that an entity 'does' something - which may be done 'to' some other entity. The second represents our sensations, which can be linked to our perception, affection and/or cognition. The third serves to characterize and to identify discourse entities, expressing possession, equivalence, attributes. There are also three other processes that are taken as secondary: behavioral, verbal and existential. The first is the process of physiological and psychological behavior, like breathing, dreaming, snoring, smiling, hiccupping, looking, watching, listening, and pondering (GEROT; WIGNEL, 1994, p.60). The second is the process of communication. The third is the process of existence, representing that something exists or happens.

Many aspects of interaction may be investigated through the framework developed by SFL, for instance, the ideational meaning realized by the transitivity

\footnotetext{
${ }^{1}$ Due to time and space constraints, the focus of this research is only on the processes themselves, which makes me believe that there is no need to describe in detail the notions of participants and circumstances. For more information about the transitivity system, see (Halliday, 2004).
} 
system, as proposed in this study. The construction of identity is one of these several topics which can be observed based on the SFL approach.

In a lecture given at Universidade Estadual da Paraíba, Moita Lopes (2007) claims that, in the postmodern world, the theme of 'identity' has been thoroughly discussed in academia and beyond. According to him, the interest in this subject is growing significantly because we are facing a period of identity crisis: individual, professional, sexual, social, ethical and even national.

However, the notion of identity is very broad, and it is necessary to bring a perspective that has a social background, thus being related to what is suggested by Halliday and his colleagues. The social constructionist view (MOITA LOPES, 2002) is one possibility of looking through identity issues in interactions.

Moita Lopes (2002, p. 32) stated that the construction of social identity is closely related to how individuals behave when they are interacting in different social contexts. In this view, both speech and identity are socially constructed and they also have a dialogical nature. Under this perspective, the author argues that "it is the presence of others with whom we are engaged in discourse that ultimately shapes what we say, and therefore how we perceive ourselves in light of what the others mean to us" (ibid, p. 32). Thus, he concludes that identities are fluid and fragmented, as they are built in language and in social interaction, a view which is totally suitable for the purpose of this article.

\section{METHODOLOGY}

This research follows a qualitative and interpretive paradigm (DENZIN; LINCOLN, 2006), in which I analyzed a TV interview ${ }^{2}$ with comedian Chico Anysio as he narrates what he experienced throughout life in general. It went on air on August $28^{\text {th }}$ of 2011 during a TV program called Fantástico ${ }^{3}$, when he commented on six different topics: a brief introduction, the beginning, the artist, success, overcoming and life.

\footnotetext{
${ }^{2}$ To watch the full interview, click on the following link: http://g1.globo.com/fantastico/quadros/o-quevi-da-vida/noticia/2011/08/chico-anysio-quero-renovar-meu-contrato-por-mais-20-anos.html

${ }^{3}$ Fantástico is a Brazilian weekly television newsmagazine broadcast that has been on air on Sunday nights on Rede Globo since August 5th, 1973. It is recognized as one of the best programs on Brazilian television, besides being the most watched program on Sunday.
} 
The full interview lasts approximately eight minutes, but, for the purpose of this research, only the segments containing identity construction in light of the transitivity system were taken into account in the analysis. Considering the applicability of the data to the pedagogical social context, this specific video was chosen for three main reasons: (i) the popularity Chico Anysio has in the Brazilian scenario among individuals of different age groups and social classes, (ii) the importance of using real life texts, whether written/spoken, inside the classroom and (iii) the narrative nature of the video, which may help students make sense of their own life stories, allowing them to take ownership of their behavior, thoughts and discourse.

The linguistic elements analyzed were manually selected from careful reading of the interview, which was heard and transcribed several times during the process of writing this paper. Since it is a selection process, that is, a recreation of the data, it should be noted that the analysis in the next section is one of many possible interpretations, thus I do not intend to be categorical.

\section{ANALYSIS}

The following analysis aims to illustrate how comedian Chico Anysio constructed multiple and dynamic identities through discourse, using the transitivity system as an analytical tool. It suggests that when he speaks, he does not refer to one specific event separate from the others, that is to say, when Chico Anysio describes his personal experiences in relation to his career, for instance, he does not dissociate the memories of his life as an artist from his memories of his private life. In fact, the process of narrating an episode, from what I could observe, involves a whole network of memories, no matter whether it contains personal and/or professional experiences.

Additionally, it is worth mentioning the relational and productive condition of discourse, affecting not only what Chico Anysio declared about himself, but also the construction of his numerous identities.

\section{Sample 1}

"A primeira etapa da minha infância foi no Ceará, onde meu pai era rico, muito rico. Um incêndio destruiu tudo que meu pai tinha e ele ficou pobre, muito pobre. Então mandou a família pro Rio, para morar numa pensão, com vergonha da decadência lá em Fortaleza e tal. E a minha infância no Rio de Janeiro dos 9 aos 15 foi péssima, foi terrível porque eu era muito responsável. Qualquer coisa que acontecia o responsável era eu. E eu apanhei muito, apanhei demais da conta, apanhei. É, apanhei tanto que um dia o Zenito, meu irmão, chutou a bola, quebrou um vidro, e eu falei: "fala que foi eu. Eu já vou apanhar mesmo, então apanho pela bola também”. 
In this sample, Chico Anysio is invited to make a brief introduction about his own life. He starts it by mentioning where he spent the first part of his childhood and also by evaluating his father's social position. However, there were some changes in his life: due to a fire that destroyed all the family's belongings, they were sent to Rio de Janeiro, completely poor.

He goes on judging his childhood and telling what happened to him the most at that time. The way Chico Anysio narrates it indicates that his childhood was not easy to endure. In order to create this identity of someone who went through tough moments, he makes use of relational and material processes mainly.

Relational processes can be understood as a way to introduce a classification to a term that precedes it. In other words, they serve to define, characterize and identify, attributing qualities, possession or circumstances, thus they build the experiences of the world and the experiences of our consciousness.

This excerpt exemplifies exactly what was said above. The verb 'SER', which appears six times in this sample, is quite representative, in the sense that it expresses particular viewpoints, being a valuable resource to determine Chico Anysio's identity construction. Relational processes as the verb 'SER' seem to have a strong influence on us, interlocutors of Chico Anysio, as they are responsible for framing what was said requiring acceptance from us.

The verb 'FICAR' indicates a change of state and appears to be a synonym of 'to become'. That said, Chico Anysio's utterance emphasizes a life transformation that sets a series of events in his life.

Besides that, there are also material processes in this sample, which are basically responsible for actions and events. They are processes that carry the meaning of making or acting, creating or changing, happening or being created.

The most evident process in this sample is 'APANHAR'. Chico Anysio positions himself as the goal of the action, the one who is affected by it. That is to say, he can be understood as someone who suffered a harm he could not control, as someone who deserves sympathy for being powerless and weak. The way he made sense of his experience as a victim is so strongly portrayed, that he repeats it six times, getting to the point of accepting this punishment even without an apparent reason for it. 


\section{Sample 2}

Um outro momento muito importante foi a minha estreia no Teatro da Lagoa. Isso foi um momento inesquecível, porque eu fazia oito sessões na semana e lotei a casa uns sete meses com a lotação maior do que a casa tinha. Em todas as sessões tive cadeira extra. Então isso é uma coisa que quando eu me lembro, me arrepio. Digo: "Meu Deus, que coisa maravilhosa! E dali eu vim pra Rede Globo, aquilo me chamou pra Globo. O teatro você pode ser todo dia a mesma coisa, porque a plateia muda. Na televisão é o oposto. Você que tem que mudar, porque a plateia é a mesma. E essa plateia é exigente, mas ela recompensa a gente. Pra mim não há diversão maior do que o trabalho. Artista é isso. O Vitório Gaspar dizia: "A gente acorda cedo, vai pro set, faz a maquiagem, decora o papel, vai pra cena, o diretor manda repetir, a gente repete, a gente faz 4 vezes, a gente faz 8 vezes a mesma cena, mas é sempre melhor do que trabalhar.

In this sample, Chico Anysio is asked about his life as an artist. He starts it by making use of relational processes to attribute to his first appearance on 'Teatro da Lagoa' the title of 'very important' and 'unforgettable moment'. He justifies it by telling what he did, that is, making use of material processes putting himself in the position of the actor: "Eu fazia oito sessões na semana e lotei a casa uns sete meses com a lotação maior do que a casa tinha".

These events, for the first time in the interview, generate in him what I would call nostalgia. It is possible to say that the mental process of remembering provokes in Chico Anysio senses of feeling, thinking and perceiving as he positions himself as the sensor of these phenomenon/events, which are the sensed.

After that, Chico makes use of the relational process 'SER' and the material process 'MUDAR', as an authority on the subject, to make a comparison between working on television and in theater. And there is more: he not only brings his professional point of view to the interaction (through material and relational processes as said before), but also gives room to other voices to complement his commentary. Due to the verbal process 'DIZER', it could be assumed that discourse is a joint coproduction of many participants during the interaction (including the ones who are not present). That is to say, narratives are not simply based exclusively on the production of each speaker individually. They also have to do with a collective production, the speaker being one part of the experience (among others).

\section{Sample 3}

A vida é dura, mas é boa. Eu tenho 10 netos, 7 filhos, tenho 20 pessoas que dependem de mim. Se eu não fosse deprimido, eu seria um louco, um louco! Com toda essa responsabilidade e não ser deprimido. Então eu converso com o meu psiquiatra uma vez por semana há dezoito anos e vou conversar até a morte. Quando eu fiquei doente 
agora, fiquei muito mal, eu estive em coma 3 vezes. Eu 3 vezes eu fui desenganado pelo médico. Eu passei 110 dias, 78 na UTI, 48 sem beber água. Eu pedia água e me davam 8 pingos na língua. Então eu padeci nesses 110 dias que eu fiquei no hospital. $\mathrm{E}$ o hospital que sempre foi amigo meu, sempre foi amigo meu. Eu tinha uma frase que eu dizia assim: "Eu adoro hospital. Quando eu pagava, eu ia. Imagina agora que eu não pago. Essa frase eu já tirei do meu repertório, porque eu tô num momento com ódio de hospital. Nesse meio tempo quem mais me ajudou a me segurar foi a prece do povo. $\mathrm{O}$ povo gosta de mim. E isso pra mim vale, eu fico emocionado de falar isso.

In this sample, Chico Anysio talks about his health problems, and also about how he managed to go through this delicate situation. From this passage, I could highlight the moment he clearly assumes the role of a depressed man ("Se eu não fosse deprimido, eu seria um louco, um louco!"). This time, there is no mention of comedian Chico Anysio: instead, the person who speaks is a humanized individual expressing his anxieties with no hesitation.

Besides that, I took into consideration the moment when Chico Anysio constructs the identity of a person who becomes emotional (mental process), which can be contrasted to the idea of a comedian who is supposed to bring happiness to the public. Through the mental process 'GOSTAR', he positions himself as an object of affection of the public, saying that the public's prayers helped him a lot in overcoming these tough moments ("Nesse meio tempo quem mais me ajudou a me segurar foi a prece do povo. O povo gosta de mim. E isso pra mim vale, eu fico emocionado de falar isso").

To finish with this sample, it is worth mentioning the fact that Chico Anysio adopts the posture of a judge as he gives 'life' the statuses of 'tough', but 'good', which makes of relational processes occurrences that mark different moments of his argumentation, demonstrating how the choices made in this semiotic system called language play unique roles depending on the context of situation.

\section{Sample 4}

Eu gosto muito de uma frase do Pascal, um matemático que disse: "Não me envergonho de mudar de ideia, porque não me envergonho de pensar". Acho que tomei essa frase pra mim. Eu não me envergonho de mudar de ideia. Não me acho melhor do que ninguém, também não me acho pior do que ninguém. Sei que vou morrer e não tenho medo de morrer. Tenho pena, tenho pena de morrer, porque se eu morrer, eu não vou ver os meus netos crescerem meus bisnetos e tal. E isso me dá pena de morrer, mas medo de morrer eu não tenho. A frase "ninguém é insubstituível" aplica-se a tudo, menos ao humor, porque no humor todos somos insubstituíveis. Nunca mais vai existir um Oscarito, um Grande Otelo, um Muçum, um Rogério Cardoso, um Zacarias, um Francisco Milânia. Nunca mais, porque somos todos insubstituíveis. Eu sou isso aí. Eu sou um teimoso, eu tenho 80 anos e estou querendo renovar meu contrato se possível 
por mais 20 , porque até os 100 eu vou, devo ir, talvez eu vá.

Since it is the last part of the interview, this time Chico Anysio is asked about his life in general. That said, it is possible to identify some beliefs, values and desires represented in his discourse. Once again he collectively constructs his identity by bringing other people's voices into the interaction. In this case, his utterances are a mixture of mental and behavioral processes, illustrating his deep thoughts and his responses to them.

Chico Anysio plays the role of a reflective person, taking into consideration fear of death, change of mind, sense of shame and his opinion about himself ("Eu não me envergonho de mudar de ideia. Não me acho melhor do que ninguém, também não me acho pior do que ninguém. Sei que vou morrer e não tenho medo de morrer”). He goes on highlighting that he would feel sorry to die, because if it happened, he would miss the opportunity of seeing his grandsons growing up.

To conclude, I would like to draw the reader's attention to the final moment of the interview, when Chico Anysio makes use of an existential process ("VAI EXISTIR"). I see this as a tool to introduce a new element into the interaction, which is, in a way, responsible for the text flow; it acts as a bridge between the data presented so far and the new information, functioning as the idea that comes to occupy the center of the discussion.

In doing so, Chico Anysio aligns himself with a group of renown comedians and takes the position of someone who achieved the status of being irreplaceable, which is totally true considering the huge success he made while he was alive ("Nunca mais vai existir um Oscarito, um Grande Otelo, um Muçum, um Rogério Cardoso, um Zacarias, um Francisco Milânia. Nunca mais, porque somos todos insubstituíveis").

Chico Anysio is constantly designing and ratifying his different identities in this sample and in the previous ones. That is why I stress the importance of conducting this research beyond the border "of what is said" to "how it is said." Based on the investigation of how he constructed his identities through discourse and what discursive projections were designed, modified and ratified during the interview, I observed the sharing of experiences, a highly conversational interaction and the use of various discursive strategies, such as constructed dialogue, moments of reflection, sadness, and happiness in Chico Anysio's utterances. 


\section{THEORY IN PRACTICE}

In this section, I explore the pedagogical potential of working with Halliday's Transitivity System as methodological background to discuss identity construction in textual analysis (in this case, an interview).

To begin with, what the Transitivity System emphasizes, in my view, is that grammatical matters are not only related to the internal construction of language, but also to contextual, cultural, social and historical aspects of any piece of text, which means we, teachers/students, should always take into account extra-linguistic factors, since they directly influence our perceptions.

In this sense, to understand the ideas proposed by this theory is to realize that in a text of any genre, when working with grammatical notions, one must also consider which linguistic and non-linguistic relations were constructed, so that a critical view of language can gain space.

Rather than classifying, a pedagogical use of such an approach could be helpful to deeply describe and better understand how certain linguistic uses, found in oral/written didactic/non-didactic texts, may produce meanings that correspond to the communicative situation analyzed.

For teaching purposes, much more than a mere tool, the Transitivity System offers a range of resources that allows teachers and students to work together to reflect on their own and others' discourse, involving not only the morphosyntactic level, but also the semantic, pragmatic and textual levels.

Likewise, identity construction is also a crucial issue in this article, mainly because of its close relation with pedagogical situations, a context in which, depending on how language is perceived/taught, different identities may emerge.

Considering the relevance of school to the lives of individuals, it can be argued that the discursive practices taking place in this context - whether in the format of exercises or not - play an important role in the development of teachers' and students' awareness of their identities and those of others. In other words: the moment schools are seen as one of the socially appropriate institutions for constructing knowledge, it will become clear that meanings generated in the classroom, such as the analysis of the interview shown above, have an enormous social credit, particularly because of the number of hours per day students spend inside the classroom. 
Finally, I reinforce the view that, due to the importance of having pedagogical materials that transcend the barriers of traditional grammar, this proposal, developed from the perspective of Systemic Functional Linguistics, can be seen as an alternative to language teachers who intend to use and improve this approach.

\section{CONCLUSION}

The teaching of language and, more specifically, the teaching of grammar have been objects of research for a long time. The discussions usually refer to the fact that the methodologies adopted frequently consist of mechanical activities, sentence classifications and/or prescriptive rules. This paper, however, presented real life discourse in context as I investigated how the analysis of Chico Anysio's utterances, based on Systemic Functional Linguistics, operates for the construction of his multiple identities, as well as the pedagogical application of such an approach. In this sense, I observed to what extent a dialogue between Halliday's Transitivity System, identity construction and the classroom context can be established.

In addition, I would say that the identities Chico Anysio constructed in the interview were not phenomena to be understood as the essence of the comedian. In other words: the segments analyzed demonstrate a social actor as an agent in action shaping himself through discourse, which represents what he thinks at the moment of the speaking.

This reflection, to conclude, constitutes a great benefit for teachers and students in general, especially because, as the life experiences of different social actors gain space in academic papers and in didactic activities, the pedagogical environment becomes a place of significant social practices.

\section{REFERENCES}

CUNHA, MARIA ANGÉLICA FURTADO DA; OLIVEIRA, M. R.; MARTELOTTA, M. E. T. Linguística funcional: teoria e prática. (orgs.). Rio de Janeiro: DP\&A/Faperj, 2003.

DENZIN, N. K.; LINCOLN, Y. S. O planejamento da pesquisa qualitativa: teorias e abordagens. (2nd ed.). Porto Alegre: Artmed, 2006.

EGGINS, S. An introduction to Systemic Functional Linguistics. (2nd ed.). New York: Continuum, 1994. 
GEROT, L; WIGNELL, P. Making Sense of Functional Grammar. (1st ed.). Queensland: Gerd Stabler, AEE Publishing, 1994.

HALLIDAY, M. A. K.; HASAN, R. (1st ed.) Cohesion in English. London: Longman, 1976.

HALLIDAY, M. A. K.; HASAN, R. Language, context and text: aspects of language in a social-semiotic perspective. (2nd ed.). Oxford: Oxford University Press, 1989.

HALLIDAY, M. A. K. e MATTHIESSEN, C. An introduction to functional grammar. (3rd ed.). London: Edward Arnold, 2004.

MARTIN, J. M.; ROSE, D. Working with Discourse: meaning beyond the clause. (2nd ed.). New York: Continuum, 2003.

MARTIN, J. M.; WHITE, P. The language of evaluation: appraisal in English. (1st ed.). New York: Palgrave, 2005.

MARTÍNEZ LIROLA, M. The importance of teaching Systemic Functional Linguistics and Text Linguistics to improve writing in Bilingual Education Programs in the USA. Revista Internacional de Didáctica de las Lenguas Extranjeras, (5), p. 139-150, 2006.

MOITA LOPES, L.P. Identidades fragmentadas: a construção discursiva de raça, gênero e sexualidade em sala de aula. (1a ed.). Campinas: Mercado de Letras, 2002.

MOITA LOPES, L.P. Gêneros e sexualidades nas práticas discursivas contemporâneas: desafios em tempos queer. Campina Grande: 16 jun. 2007. Palestra proferida no IV Colóquio Nacional Representações de Gênero e de Sexualidades Questionando identidades e sujeitos nas culturas contemporâneas.

THOMPSON, G. Introducing Functional Grammar. (2nd ed.). Oxford: Oxford University Press, 2003.

\section{O AUTOR}

Renan Silva da Piedade é mestrando em Estudos da Linguagem (PUC-RIO). Graduouse em Letras (Português/Inglês) pela mesma instituição. É membro do grupo de pesquisa Análise Literária e Sistêmico Funcional (ALESF/CNPq) e atua como professor de línguas, tendo como áreas de interesse estudos em Linguística Aplicada, Prática Exploratória e Análise do Discurso. 


\section{APPENDIX}

\section{Full transcript: Chico Anysio: "Quero renovar meu contrato por mais 20 anos" Published: August 28th, 2011.}

\section{Introdução}

A primeira etapa da minha infância foi no Ceará, onde meu pai era rico, muito rico. Um incêndio destruiu tudo que meu pai tinha e ele ficou pobre, muito pobre. Então mandou a família pro Rio, para morar numa pensão, com vergonha da decadência lá em Fortaleza e tal. E a minha infância no Rio de Janeiro dos 9 aos 15 foi péssima, foi terrível porque eu era muito responsável. Qualquer coisa que acontecia o responsável era eu. E eu apanhei muito, apanhei demais da conta, apanhei. É, apanhei tanto que um dia o Zenito, meu irmão, chutou a bola, quebrou um vidro, e eu falei: "fala que foi eu. Eu já vou apanhar mesmo, então apanho pela bola também".

\section{O começo}

Eu deveria ter sido advogado criminalista e tal. Mas aí nós íamos jogar uma pelada com a turma da rua. Eu falei: "Então eu vou em casa buscar um tênis, mas vocês vão indo que eu já vou". Voltei pra casa pra pegar o tênis. Por isso eu digo que sou artista porque esqueci o tênis. Quando eu ia entrando em casa, minha irmã ia saindo com o amigo dela, o Oromar. "Onde é que vocês vão?", eu não tinha o direito de perguntar aquilo. Você vê como a vida é. Eu perguntei e ela poderia me dizer "não interessa". E aí ela disse "vamos fazer o teste da Rádio Guanabara, o teste de rádio ator". Aí eu falei: "Ah, então eu vou com vocês. Eu fiz o teste de rádio ator e tirei em $7^{\circ}$ lugar. Fiz o teste de rádio locutor e tirei em $2^{\circ}$ lugar, o Sílvio Santos ganhou. Você veja bem que em 10 dias, eu que era quase um pretenso advogado, eu já tinha 4 profissões: era rádio ator, redator, locutor e comentarista de futebol.

\section{O artista}

Um outro momento muito importante foi a minha estreia no Teatro da Lagoa. Isso foi um momento inesquecível, porque eu fazia oito sessões na semana e lotei a casa uns sete meses com a lotação maior do que a casa tinha. Em todas as sessões tive cadeira extra. Então isso é uma coisa que quando eu me lembro, me arrepio. Digo: "Meu Deus, que coisa maravilhosa! E dali eu vim pra Rede Globo, aquilo me chamou pra Globo. O teatro você pode ser todo dia a mesma coisa, porque a plateia muda. Na televisão é o oposto. Você que tem que mudar, porque a plateia é a mesma. E essa plateia é exigente, mas ela recompensa a gente. Pra mim não há diversão maior do que o trabalho. Artista é isso. O Vitório Gaspar dizia: "A gente acorda cedo, vai pro set, faz a maquiagem, decora o papel, vai pra cena, o diretor manda repetir, a gente repete, a gente faz 4 vezes, a gente faz 8 vezes a mesma cena, mas é sempre melhor do que trabalhar.

\section{O sucesso}

O sucesso é um acidente de percurso. Não pense que o sucesso seja eterno. É muito difícil que ela seja. Então não humilhe ninguém, mantenha-se humilde, porque daqui a pouco você não sabe como será.

\section{A superação}

A vida é dura, mas é boa. Eu tenho 10 netos, 7 filhos, tenho 20 pessoas que dependem de mim. Se eu não fosse deprimido, eu seria um louco, um louco! Com toda essa responsabilidade e não ser deprimido. Então eu converso com o meu psiquiatra uma vez por semana há dezoito anos e vou conversar até a morte. Quando eu fiquei doente agora, 
fiquei muito mal, eu estive em coma 3 vezes. Eu 3 vezes eu fui desenganado pelo médico. Eu passei 110 dias, 78 na UTI, 48 sem beber água. Eu pedia água e me davam 8 pingos na língua. Então eu padeci nesses 110 dias que eu fiquei no hospital. E o hospital que sempre foi amigo meu, sempre foi amigo meu. Eu tinha uma frase que eu dizia assim: "Eu adoro hospital. Quando eu pagava, eu ia. Imagina agora que eu não pago. Essa frase eu já tirei do meu repertório, porque eu tô num momento com ódio de hospital. Nesse meio tempo quem mais me ajudou a me segurar foi a prece do povo. $\mathrm{O}$ povo gosta de mim. E isso pra mim vale, eu fico emocionado de falar isso.

\begin{abstract}
A vida
Eu gosto muito de uma frase do Pascal, um matemático que disse: "Não me envergonho de mudar de ideia, porque não me envergonho de pensar". Acho que tomei essa frase pra mim. Eu não me envergonho de mudar de ideia. Não me acho melhor do que ninguém, também não me acho pior do que ninguém. Sei que vou morrer e não tenho medo de morrer. Tenho pena, tenho pena de morrer, porque se eu morrer, eu não vou ver os meus netos crescerem meus bisnetos e tal. $\mathrm{E}$ isso me dá pena de morrer, mas medo de morrer eu não tenho. A frase "ninguém é insubstituível" aplica-se a tudo, menos ao humor, porque no humor todos somos insubstituíveis. Nunca mais vai existir um Oscarito, um Grande Otelo, um Muçum, um Rogério Cardoso, um Zacarias, um Francisco Milânia. Nunca mais, porque somos todos insubstituíveis. Eu sou isso aí. Eu sou um teimoso, eu tenho 80 anos e estou querendo renovar meu contrato se possível por mais 20, porque até os 100 eu vou, devo ir, talvez eu vá.
\end{abstract}

